\title{
EFFECT OF SEED RATE AND ROW SPACING ON GRAIN YIELD OF SORGHUM
}

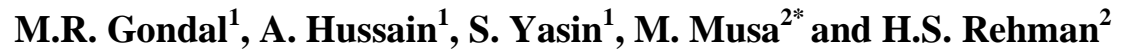 \\ ${ }^{1}$ Fodder Research Institute, Sargodha, Pakistan \\ ${ }^{2}$ Ayub Agricultural Research Institute, Faisalabad, Pakistan
}

\begin{abstract}
An experiment to investigate the effect of seed rate $(5,7.5,10,12.5$ and $15 \mathrm{~kg} \mathrm{ha}^{-1}$ ) and row spacing $(30,45$ and $60 \mathrm{~cm})$ on agronomic characteristics of plants including stem densitym ${ }^{-2}$, plant height, stem diameter, number of heads $\mathrm{m}^{-2}$, number of heads per plant, number of grains per head, 1000-grain weight and grain yield was conducted using the cultivar "Sorghum 2011" for two years 2016 and 2017. Seed rates and row spacing had significant effect on plant height, plant density $\mathrm{m}^{-2}$, number of heads $\mathrm{m}^{-2}$, number of grains per head and grain yield. Row spacing had non-significant effect on stem diameter, number of heads per plant and 1000-grain weight. Row spacing at $30 \mathrm{~cm}$ produced the highest number of plants $\mathrm{m}^{-2}$ and plant height. Plant height increased with increase in seed rate in all the row spacing. Stem diameter decreased with increase in the seed rate and row spacing. Narrow row spacing $(30 \mathrm{~cm})$ and low seeding rate $\left(5 \mathrm{~kg} \mathrm{ha}^{-1}\right)$ produced the maximum grain yield consistently during both years. Lower yields were recorded in the treatments having greater row spacing $(60 \mathrm{~cm})$ and higher seed rates $\left(7.5,10,12.5 \& 15 \mathrm{~kg} \mathrm{ha}^{-1}\right)$. Higher seed rates and wider row spacing induced morphological changes rendering plants to lodging.
\end{abstract}

Keywords: Sorghum bicolor, seed rate, row spacing, grain yield.

\section{INTRODUCTION}

Seed rate and row spacing are important factors for crop establishment technique that affects the crop stand and other yield parameters in different crops. Maintenance of optimum planting density is always a big problem to the farmers. Lower plant density results in higher weed infestation, poor radiation use efficiency and lower yields. On the other hand, dense plant population may cause lodging, poor light penetration in the canopy, reduction of photosynthesis due to shading of lower leaves and serious reduction in the yield (Lemerle et al., 2004; Lemerle et al., 2006). Similarly, plant population, on the basis of row spacing and seed rate, affects the crop stand,

\footnotetext{
*Corresponding authors e-mail: mum96@hotmail.com
} 
agronomic plant characteristics and the yield in sorghum crop (McMurray, 2004; McRae et al., 2008).

Tillering is an important morphological component of grain sorghum (Sorghum bicolor L. Moench) development because it affects light capture, water use, grain yield, plant competition and other physical and biological processes (Krishnareddy et al., 2006). It has also been reported that increase in plant population results in decrease in number of tillers (Pawlowski et al, 1993; Caliskan et al., 2007), plant height (Ayub et al., 2003) and stem diameter (Caravetta et al., 1990) but grain yield per unit area increased (Caliskan et al., 2007).

Row spacing affects the crop yield potential (Staggenborg, 1999; Bryant et al., 1986). Reducing the distance between rows improves weed control (Walker \& Buchanan, 1982) by increasing crop competition and reducing light transmission to the soil (Andrade et al., 2002). Narrow row spacing results in higher grain yields in soybean (De Bruin \& Pederson, 2008) and in other crops (Stickler \& Laude, 1960). Narrow row spacing resulting in higher yield is explained by the improved light interception (Steiner, 1986) and decreased plant to plant competition between plants (De Bruin \& Pederson, 2008). Johnson et al. (2005) reported reduction in total weed density in $30 \mathrm{~cm}$ apart rows of peanut (Arachis hypogea) as compared to the weed density at greater spacing.

Grain sorghum is commonly cultivated in rows with 60 to $75 \mathrm{~cm}$ spacing, but with the development new production technology and introduction of new herbicides has opened a new window of opportunity to test narrower row spacing for grain production of sorghum. Determining the optimum seed rate is essential to get the proper crop stand and maximum yield (Cox, 1996; Widdicombe \& Thelen, 2002) of sorghum crop. The aim of this research was to study the effect of seed rate and row spacing on different attributes of sorghum in order to get maximum grain yield of sorghum crop.

\section{MATERIALS AND METHODS}

This study was conducted at experimental field of Fodder Research Institute (FRI), Sargodha, Pakistan during the years 2015 and 2016 to investigate the proper seed rate with relation to row spacing of new variety "Sorghum 2011". The experiment was laid out in split plot design keeping row spacing $(30,45 \& 60 \mathrm{~cm}$ apart) in main plots and seeding rate $\left(5,7.5,10,12.5 \& 15 \mathrm{~kg} \mathrm{ha}^{-1}\right)$ in sub-plots measuring $2.7 \mathrm{~m} \times 5 \mathrm{~m}$ with three replications. The experiment was sown on $2^{\text {nd }}$ week of July during both years. Sowing was done with the help of hand drill. First irrigation was given after 25 days of sowing. The subsequent irrigations were adjusted according to the climatic conditions and need of the crop. Fertilizer @ 57-57-57 NPK kg ha ${ }^{-1}$ was applied during both years. 
Data on plant height, stem diameter, stem density (number of plants) $\mathrm{m}^{-2}$, number of headm ${ }^{-2}$, number of heads plant ${ }^{-1}$,numbers of grains head ${ }^{-1}, 1000$-grain weight and grain yield ha ${ }^{-1}$ were recorded.

The trend of data collected during two years was found similar. So, the data were averaged. The data averaged on two years were analyzed statistically and differences among the treatment means were compared by using the least significant difference (LSD) test at 0.05 probability level with the help of M-Stat C programme.

\section{RESULTS AND DISCUSSION}

Significant differences among row spacing, seed rates and interaction of both the variables were found for number of grains per head, number of headsm ${ }^{-2}$, stem density $\mathrm{m}^{-2}$ and stem diameter in the combined results of two years (Table 1).

Plant height increased with increasing seed rate and decreasing row spacing. The combined effect of row spacing and seed rate, the interaction, had no effect on plant height (Table 1). Snider et al. (2012) also reported the effect of seeding rate on the plant height to be significant but contrasting effects at different sites. Higher seeding rate may stimulate plant height due to internode elongation (Schmitt \& Wulff, 1993). The results indicated that besides genetic constitution, row spacing and seed rate also control growth behavior of sorghum plant. Data also revealed that plant height decreased with increased row spacing and decreased seed rate that probably due to plant competition for light. The maximum plant height $313.11 \mathrm{~cm}$ was recorded with seed rate of $15 \mathrm{~kg} \mathrm{ha}^{-1}$ while maximum plant height $(309.87 \mathrm{~cm})$ was recorded at $30 \mathrm{~cm}$ row spacing. Similar results of row spacing on plant height have been reported by others (Srivastava et al., 1980; Rana and Ahuja, 1986).

Stem diameter was affected by seeding rate but row spacing had no effect on stem diameter (Table 1).Increase in seed rate from $5 \mathrm{~kg} \mathrm{ha}^{-1}$ to $15 \mathrm{~kg} \mathrm{ha}^{-1}$ resulted in a significant decrease in stem diameter while increased the stem density. This is due to the fact that higher seed rate directly results in higher stem density and a higher stem density resulting in decrease in stem diameter due to the obvious interplant competition (Schmitt \& Wulff, 1993; Van Der Werf et al., 1995). Higher plant density produces thin stemmed plants that tend to lodge (Kashiwagi et al., 2008; Venuto \& Kindiger, 2008) and high seeding rates should be avoided for sorghum in regions where lodging is a major concern. The effect of interaction between seeding rate and row spacing on stem diameter was significant (Figure 1).No significant effect of increasing the row spacing within a given seed rate was recorded on the stem thickness, however at the highest seed rate $\left(15 \mathrm{~kg} \mathrm{ha}^{-1}\right)$, the stem thickness decreased significantly as the row spacing increased to $60 \mathrm{~cm}$. The maximum stem diameter $(1.88 \mathrm{~cm})$ was recorded from the treatment interaction of the lowest seed rate $\left(5 \mathrm{~kg} \mathrm{ha}^{-1}\right)$ with the least row spacing $(30 \mathrm{~cm})$ and the interaction of statistically similar stem thickness $(1.88 \mathrm{~cm})$ from the interaction of the lowest seed rate $(30 \mathrm{~cm})$ and wider row spacing $(45 \& 60 \mathrm{~cm})$. 
Table 1. Effect of seeding rates and row spacing on yield and yield components of sorghum (2-year average)

\begin{tabular}{|c|c|c|c|c|c|c|c|c|}
\hline Treatments & $\begin{array}{l}\text { Plant Height } \\
\text { (cm) }\end{array}$ & $\begin{array}{c}\text { Stem } \\
\text { Diameter }(\mathrm{cm})\end{array}$ & $\begin{array}{c}\text { Stem Density } \\
\mathrm{m}^{-2}\end{array}$ & $\begin{array}{c}\text { No. of Heads } \\
\mathrm{m}^{-2}\end{array}$ & $\begin{array}{c}\text { No. of } \\
\text { Headsplant }^{-1}\end{array}$ & $\begin{array}{l}\text { 1000-grain } \\
\text { Weight }(\mathrm{g})\end{array}$ & $\begin{array}{c}\text { No. of Grains } \\
\text { head }^{-1}\end{array}$ & $\begin{array}{c}\text { Grain Yield } \\
\left(\mathrm{kg} \mathrm{ha}^{-1}\right)\end{array}$ \\
\hline $\mathrm{SR}_{1}\left(5 \mathrm{~kg} \mathrm{ha}^{-1}\right)$ & $281.67 \mathrm{e}$ & $1.88 \mathrm{a}$ & $25.44 \mathrm{e}$ & $21.22 \mathrm{e}$ & $0.843 \mathrm{a}$ & $17.14 \mathrm{a}$ & $1020.6 \mathrm{a}$ & $2996 \mathrm{a}$ \\
\hline $\mathrm{SR}_{2}\left(7.5 \mathrm{~kg} \mathrm{ha}^{-1}\right)$ & $291.22 d$ & $1.82 \mathrm{~b}$ & $31.11 \mathrm{~d}$ & $25.00 \mathrm{~d}$ & $0.803 a b$ & $16.76 \mathrm{~b}$ & $797.2 b$ & $2766 \mathrm{~b}$ \\
\hline $\mathrm{SR}_{3}\left(10 \mathrm{~kg} \mathrm{ha}^{-1}\right)$ & $297.44 \mathrm{c}$ & $1.78 \mathrm{c}$ & $40.33 c$ & $31.22 \mathrm{c}$ & $0.774 \mathrm{bc}$ & $16.21 \mathrm{c}$ & $648.0 \mathrm{c}$ & $2557 \mathrm{c}$ \\
\hline $\mathrm{SR}_{4}\left(12.5 \mathrm{~kg} \mathrm{ha}^{-1}\right)$ & $308.67 b$ & $1.73 d$ & $51.67 \mathrm{~b}$ & $38.11 \mathrm{~b}$ & $0.738 \mathrm{~cd}$ & $15.81 \mathrm{~d}$ & $536.0 \mathrm{~d}$ & $2357 d$ \\
\hline $\mathrm{SR}_{5}\left(15 \mathrm{~kg} \mathrm{ha}^{-1}\right)$ & $313.11 \mathrm{a}$ & $1.60 \mathrm{e}$ & $59.67 \mathrm{a}$ & $42.67 \mathrm{a}$ & $0.716 \mathrm{~d}$ & $15.18 \mathrm{e}$ & $489.4 \mathrm{e}$ & 2329d \\
\hline $\operatorname{LSD}(0.05)$ & 3.374 & 0.021 & 2.099 & 2.112 & 0.0497 & 0.133 & 35.27 & 141.49 \\
\hline $\mathrm{RS}_{1}(30 \mathrm{~cm})$ & $309.87 \mathrm{a}$ & 1.78 & $43.60 \mathrm{a}$ & $33.27 \mathrm{a}$ & 0.781 & 16.28 & 757.9 a & $2747 \mathrm{a}$ \\
\hline $\mathrm{RS}_{2}(45 \mathrm{~cm})$ & $297.40 \mathrm{~b}$ & 1.76 & $41.00 \mathrm{~b}$ & $30.40 \mathrm{~b}$ & 0.761 & 16.21 & $693.7 \mathrm{~b}$ & $2622 a b$ \\
\hline $\mathrm{RS}_{3}(60 \mathrm{~cm})$ & $288.00 \mathrm{c}$ & 1.75 & $40.33 b$ & $31.27 \mathrm{~b}$ & 0.783 & 16.16 & $643.1 \mathrm{c}$ & $2433 \mathrm{~b}$ \\
\hline $\operatorname{LSD}(0.05)$ & 4.670 & $N S$ & 1.894 & 1.753 & $N S$ & $N S$ & 25.62 & 222.86 \\
\hline $\mathrm{RS}_{1} \mathrm{SR}_{1}$ & 296.00 & $1.88 \mathrm{a}$ & $23.33 \mathrm{~g}$ & $19.67 \mathrm{~g}$ & 0.830 & 17.22 & $1157.7 \mathrm{a}$ & 3257 \\
\hline $\mathrm{RS}_{1} \mathrm{SR}_{2}$ & 302.00 & $1.83 \mathrm{bc}$ & $30.33 \mathrm{f}$ & $24.67 \mathrm{f}$ & 0.809 & 16.88 & $880.0 \mathrm{c}$ & 2983 \\
\hline $\mathrm{RS}_{1} \mathrm{SR}_{3}$ & 310.00 & $1.81 \mathrm{~cd}$ & $43.67 \mathrm{~d}$ & $34.33 \mathrm{~d}$ & 0.787 & 16.37 & $662.3 \mathrm{ef}$ & 2690 \\
\hline $\mathrm{RS}_{1} \mathrm{SR}_{4}$ & 320.00 & $1.73 \mathrm{ef}$ & $55.67 \mathrm{~b}$ & $42.33 \mathrm{ab}$ & 0.760 & 15.85 & $579.7 \mathrm{gh}$ & 2417 \\
\hline $\mathrm{RS}_{1} \mathrm{SR}_{5}$ & 321.33 & $1.64 \mathrm{f}$ & $65.00 \mathrm{a}$ & $45.33 \mathrm{a}$ & 0.697 & 15.11 & $510.0 \mathrm{i}$ & 2390 \\
\hline $\mathrm{RS}_{2} \mathrm{SR}_{1}$ & 280.00 & $1.88 \mathrm{ab}$ & $26.67 \mathrm{~g}$ & $22.00 \mathrm{~g}$ & 0.840 & 17.17 & $997.0 \mathrm{~b}$ & 2980 \\
\hline $\mathrm{RS}_{2} \mathrm{SR}_{2}$ & 290.00 & $1.82 \mathrm{c}$ & $32.00 \mathrm{f}$ & $25.33 \mathrm{f}$ & 0.790 & 16.72 & $798.3 d$ & 2793 \\
\hline $\mathrm{RS}_{2} \mathrm{SR}_{3}$ & 295.00 & $1.77 \mathrm{de}$ & $37.33 \mathrm{e}$ & $30.00 \mathrm{e}$ & 0.803 & 16.14 & $655.0 \mathrm{ef}$ & 2650 \\
\hline $\mathrm{RS}_{2} \mathrm{SR}_{4}$ & 308.33 & $1.72 \mathrm{f}$ & $51.33 \mathrm{c}$ & $34.67 \mathrm{~d}$ & 0.677 & 15.78 & 528.3hi & 2376 \\
\hline $\mathrm{RS}_{2} \mathrm{SR}_{5}$ & 313.67 & $1.61 \mathrm{f}$ & $57.67 \mathrm{~b}$ & $40.00 \mathrm{bc}$ & 0.693 & 15.25 & $490.0 \mathrm{i}$ & 2310 \\
\hline $\mathrm{RS}_{3} \mathrm{SR}_{1}$ & 269.00 & $1.88 \mathrm{a}$ & $26.33 \mathrm{~g}$ & $22.00 \mathrm{~g}$ & 0.840 & 17.04 & $907.0 \mathrm{c}$ & 2750 \\
\hline $\mathrm{RS}_{3} \mathrm{SR}_{2}$ & 281.67 & $1.81 \mathrm{~cd}$ & $31.00 \mathrm{f}$ & $25.00 \mathrm{f}$ & 0.810 & 16.67 & $713.3 \mathrm{e}$ & 2520 \\
\hline $\mathrm{RS}_{3} \mathrm{SR}_{3}$ & 287.33 & $1.77 \mathrm{de}$ & $40.00 \mathrm{de}$ & $29.33 \mathrm{e}$ & 0.777 & 16.12 & $626.7 \mathrm{fg}$ & 2330 \\
\hline $\mathrm{RS}_{3} \mathrm{SR}_{4}$ & 297.67 & $1.73 \mathrm{ef}$ & $48.00 \mathrm{c}$ & $37.33 \mathrm{~cd}$ & 0.757 & 15.80 & $500.0 \mathrm{i}$ & 2277 \\
\hline $\mathrm{RS}_{3} \mathrm{SR}_{5}$ & 304.33 & $1.55 \mathrm{~g}$ & $56.33 \mathrm{~b}$ & $42.67 \mathrm{ab}$ & 0.733 & 15.17 & $468.3 \mathrm{i}$ & 2287 \\
\hline $\operatorname{LSD}(0.05)$ & $N S$ & 0.044 & 3.636 & 3.658 & $N S$ & $N S$ & 61.10 & $N S$ \\
\hline
\end{tabular}

$\mathrm{SR}=$ Seed Rate, $\mathrm{RS}=$ Row spacin 


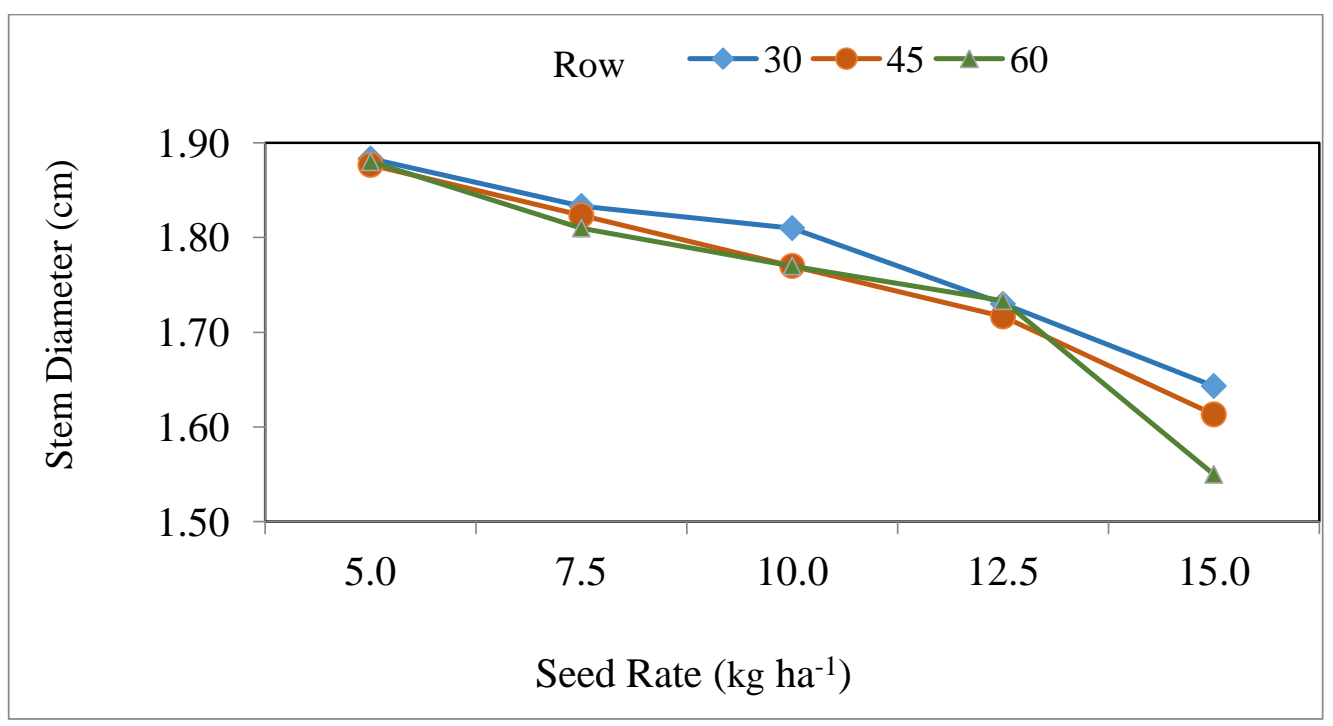

Figure 1. Interactive effect of seed rate and row spacing on stem diameter of sorghum.

Stem density (number of plants $\mathrm{m}^{-2}$ ) was statistically higher in the narrow row spacing $(30 \mathrm{~cm})$ than those in wider row spacing of $45 \mathrm{~cm}$ and $60 \mathrm{~cm}$. (Table 1). Increase in seed rate from 5 to $15 \mathrm{~kg} \mathrm{ha}^{-1}$ resulted in increased stem density from 25.44 to $59.67 \mathrm{stem}^{-2}$. Interaction between seeding rate and row spacing was significant for stem density (Figure 2). A trend of differences in the stem density due to interaction between seed rate and row spacing was recorded to be more prominent due to different row spacing interaction with the highest seed rate. Among all the

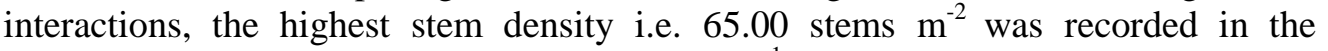
interaction of $30 \mathrm{~cm}$ row spacing with $15 \mathrm{~kg} \mathrm{ha}^{-1}$ seed rate followed by statistically

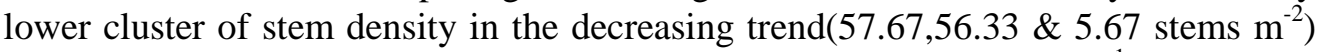
in the interactions of $45 \mathrm{~cm}$ row spacing and seed rate of $15 \mathrm{~kg} \mathrm{ha}^{-1} ; 60 \mathrm{~cm}$ row spacing and seed rate of $15 \mathrm{~kg} \mathrm{ha}^{-1}$; and $30 \mathrm{~cm}$ row spacing and seed rate of $12.5 \mathrm{~kg}$ $\mathrm{ha}^{-1}$. All the other interactions resulted in further statistically different and lower stem density clusters with the least stem density in three interactions of $60 \mathrm{~cm}, 45 \mathrm{~cm}$ and $30 \mathrm{~cm}$ at $5 \mathrm{~kg} \mathrm{ha}^{-1}$ seed rate having 21.00, 20.67 and 19.67 stem densities in the decreasing trend, respectively. Similar results have been reported by Snider et al. (2012) stating that plant stand establishment may be more favorable under narrow row spacing as compared to wider row spacing i.e. $76 \mathrm{~cm}$ row spacing, owing to more number of seeds per length of row resulting in increased intra-row competition among plants during the early plant establishment. Such observations have been recorded for other crop species as well (De Bruin \& Pedersen, 2008) suggesting decrease in the plant population by increasing row spacing caused by the intra-row competition between plants. 


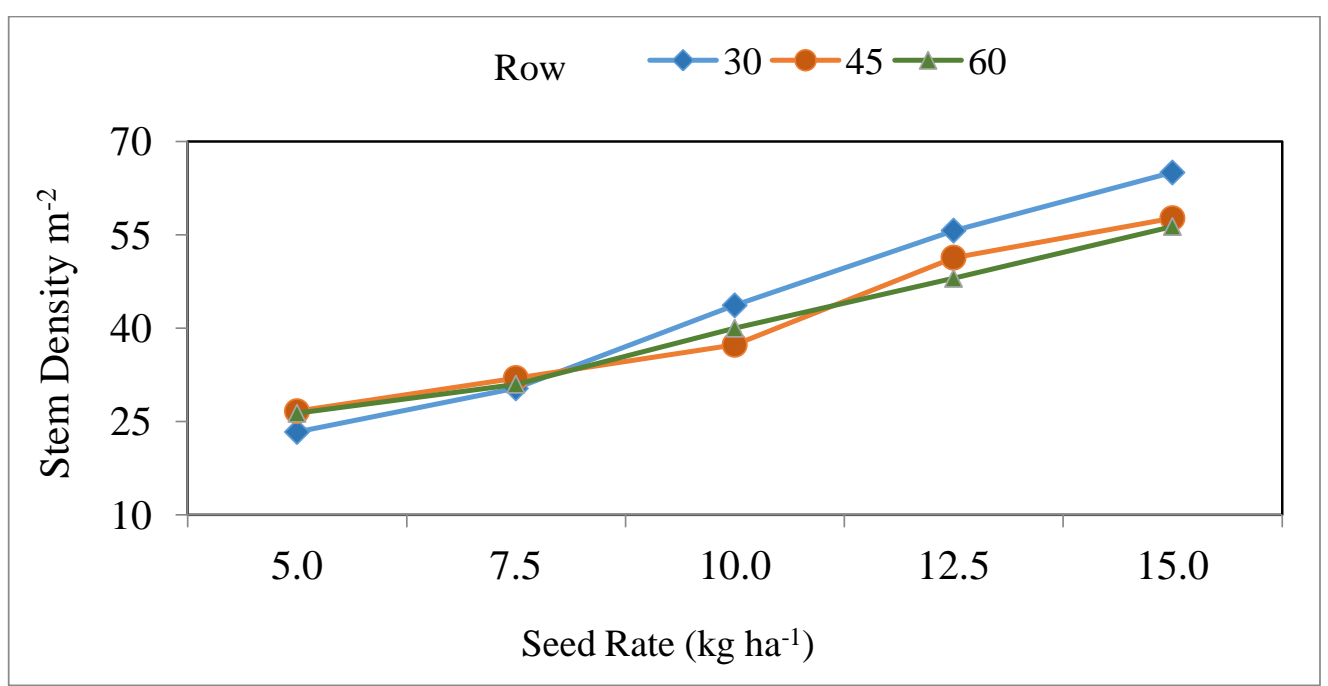

Figure 2. Interactive effect of seed rate and row spacing on density $\mathrm{m}^{-2}$ of sorghum

The trend of number of viable heads $\mathrm{m}^{-2}$ was similar to that of stem density (Table 1). All treatments of seed rate differed significantly from each other for their effect on the number of viable heads $\mathrm{m}^{-2}$, producing the highest number of viable heads $\mathrm{m}^{-}$ ${ }^{2}(42.67)$ in the highest seed rate decreasing with the decrease in the seed rate. This behavior is due to the fact that using the highest seed rate at the narrow row spacing $(30 \mathrm{~cm})$ would accommodate more number of lines resulting in greater plant to plant distance within the row providing more space to the individual plants for their establishment. Mascagni \& Bell (2005) also reported that there had been more tillering for twin rows since the intra-row spacing was greater than the single row for a given seeding rate. The result of number of heads $\mathrm{m}^{-2}$ had no effect on sorghum grain yield $\mathrm{ha}^{-1}$ and this behavior of sorghum crop is supported by the studies of Mascagni \& Bell (2005). The interaction between spacing and seed rate was significant for its effect on the number of viable head $\mathrm{m}^{-2}$ (Figure 3). The percentage of head formation on plants was affected significantly with varying the seed rate showing an overall trend of decrease in head formation as the seed rate was increased. The highest percentage of head formation $(83.41 \%)$ was recorded at $5 \mathrm{~kg}$ seed ha ${ }^{-1}$, having 254,400 plants $^{-1}$, followed by statistically similar $7.5 \mathrm{~kg}$ seed ha ${ }^{1}$, having 311,100 plants $\mathrm{ha}^{-1}$, producing heads on $80.36 \%$ plants. A further decrease of head formation was recorded as the seed rate increased (Table 1). In case of two lower seed rates i.e. $5 \mathrm{~kg} \mathrm{ha}^{-1}$ and $7.5 \mathrm{~kg} \mathrm{ha}^{-1}$,the intra-row spacing was greater than the higher seed rate and the production of higher percentage was recorded due to the phenomenon explained earlier as for the establishment of plants. Earlier studies have reported that a single row planting, having 124,000-160,000 plant ha ${ }^{-1}$, produced a greater number of heads plant ${ }^{-1}$ than the twin row planting at any population (Fernandez et al., 2012). They also reported that $76 \mathrm{~cm}$ row spacing planted 210,000 
to 240,000 plants $\mathrm{ha}^{-1}$ produced the greatest number of heads per plant than the lower plant population at $76 \mathrm{~cm}$ row spacing. The results of the current studies are in agreement with the earlier studies reported.

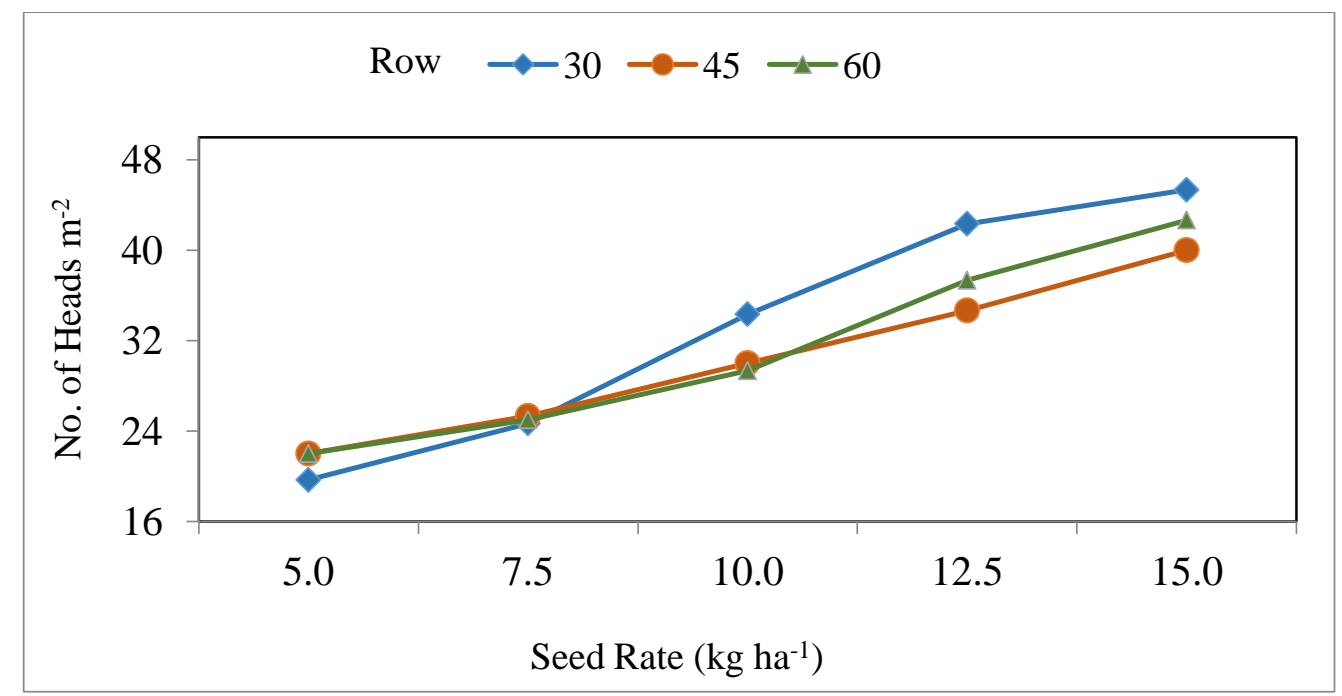

Figure 3. Interactive effect of seed rate and row spacing on number of heads $\mathrm{m}^{-2}$ of sorghum.

The effect of row spacing on 1000-grain weight did not differ significantly. On the other hand, seed rates affected 1000-grain weight significantly showing a continuous trend of reduction in the 1000-grain weight as the seed rate was increased. The highest 1000-grain weight of $17.14 \mathrm{~g}$ was recorded at $5 \mathrm{~kg} \mathrm{ha}^{-1}$ seed rate (Table 1). The parameter of increase in 1000-grain weight was reflected in the grain yield increase confirming its contributive factor for grain yield. This study was supported by Fernandez et al. (2012) reporting that the single-row planting at low plant population produced the highest grain weight.

Number of grains per head plays an important role in grain yield of sorghum crop. In the present study, all seed rates were significantly different, producing the highest number of grain per head (1020.6) in the $5 \mathrm{~kg}$ seed ha ${ }^{-1}$. Similarly, closer row spacing $(30 \mathrm{~cm})$ produced the highest number of grain per head $(757.93)$. The results of the interaction between seed rate and row spacing depicted that the lowest $5 \mathrm{~kg}$ seed ha ${ }^{1}$ with narrow row spacing of $30 \mathrm{~cm}$ was the best combination, producing 1157.7 grains per head (Table 1). At all three row spacings, number of grains per head decreased with the increase of seed rate (Figure 4). While at all five seed rates, number of grains per head decreased with increase of row spacing (Figure 4). The increase in number of grains per head by using different seed rates, row spacing or the geometry of sowing pattern has been attributed basically due low plant population or more plant to plant distance (Fernandez et al., 2012). The number of seed per head plays an important role in yield determination and has been reported to contribute 
$70 \%$ towards grain yield sorghum as reported by Karchi \& Rudich (1966). The current study was in confirmation of number of grains per head playing a major contributive role towards grain yield of sorghum.

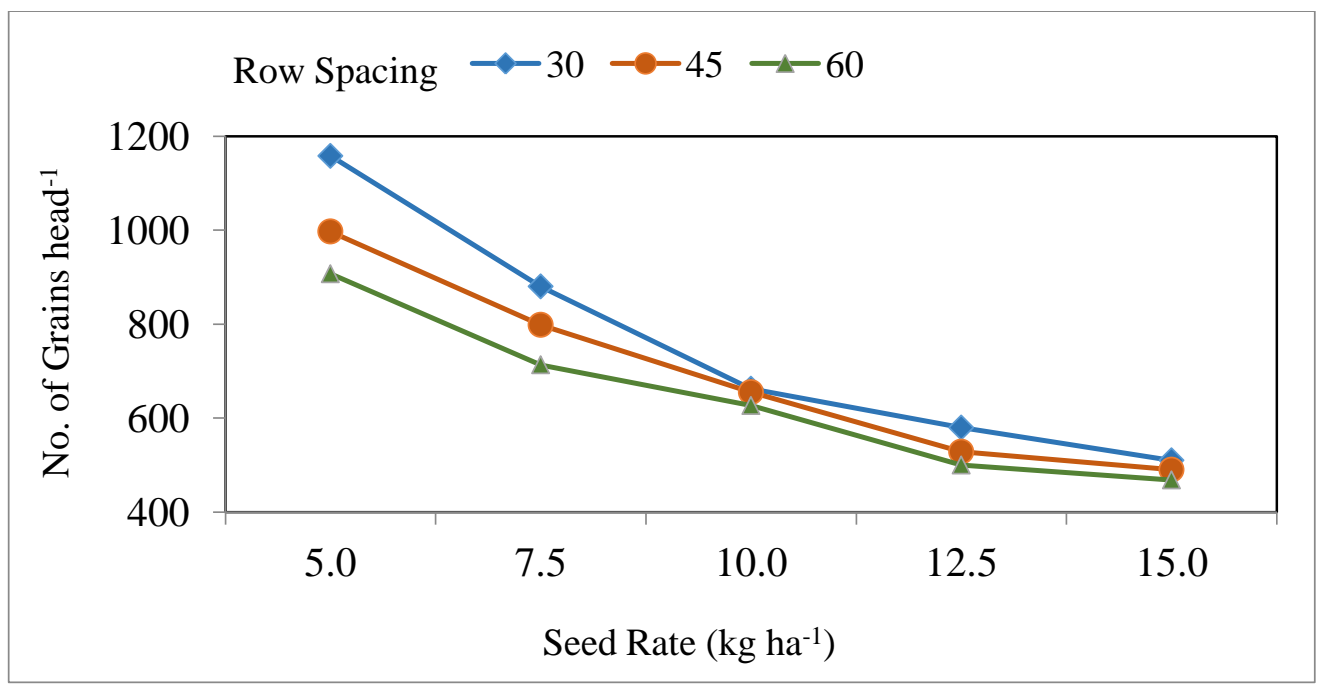

Figure 4. Interactive effect of seed rate and row spacing on number of grains head ${ }^{-1}$ of sorghum

The maximum grain yield $\left(2747 \mathrm{~kg} \mathrm{ha}^{-1}\right)$ was obtained with row spacing at $30 \mathrm{~cm}$ that was statistically at par with that of $45 \mathrm{~cm}$ apart row $\left(2622 \mathrm{~kg} \mathrm{ha}^{-1}\right)$ but significantly higher than the grain yield $\left(2433 \mathrm{~kg} \mathrm{ha}^{-1}\right)$ obtained from row spacing at $60 \mathrm{~cm}$ apart (Table 1).Similar response to row spacing has been reported in previous studies where similar row spacing produced higher yields of sorghum grains (Stickler \& Laude, 1960; Steiner, 1986), forage (Stickler \& Laude, 1960) and other crops such as soybean (De Bruin \& Pedersen, 2008). Higher biomass production of sorghum crop with a narrower row spacing of $19 \mathrm{~cm}$ has been mentioned by $S$ nider et al. (2012), and the phenomenon might be due to the better light interception (Steiner, 1986) and decreased inter-row competition between pants (De Bruin \& Pederson, 2008). In contrast, the seed rate studies showed constant decrease in the grain yield with increase in the seed rate (Table 1). Snider et al. (2012) have reported a significant yield reduction with increase in seeding rate from 218,000 to $393,000 \mathrm{ha}^{-1}$; however the seeding rate 116,000 to $291,000 \mathrm{ha}^{-1}$ did not affect the yields. Higher seed rates have been reported as to increase dry matter production but, in other cases on the contrary, no such effect has been reported to showing inconsistency (Habyarimana et al., 2004; Wortmann et al., 2010). According to the current studies, $30 \mathrm{~cm}$ row spacing and $5 \mathrm{~kg}$ seed ha ${ }^{-1}$, requiring the least inputs, were found to be the optimum, among the tested seed rates and row spacing levels, for better aboveground biomass and yield of the cultivar "Sorghum 2011" (Table 1).These findings 
suggests a phenomenon that for any given seed rate tested better crop stand can be established by $30 \mathrm{~cm}$ apart row spacing as compared to other row spacing. This behavior might be attributed to the fact that at wider row spacing of $60 \mathrm{~cm}$, each row would receive a higher number of seeds, increasing the number of plants per row, and the intra-row plants would suffer from increased plant-to-plant competition during the early plant establishment stage. Similar results have been depicted from other studies as well in other crops (De Bruin \& Pederson, 2008).

These studies indicated consistent increase in plant density $\mathrm{m}^{-2}$ with increase in the seed rate in sorghum cultivar "Sorghum 2011". Such increase in plant population by increasing the seed rate has been reported by other workers (Geleta et al., 2002; Habyarimana et al., 2004; Wortmam et al., 2010) and an interplant competition has been reported to have pronounced effect leading to self-thinning at higher seeding rates of some species (Van Der Werf et al., 1995 ) decreasing the yield.

\section{CONCLUSIONS}

Increasing the seed rate from $5 \mathrm{~kg} \mathrm{ha}^{-1}\left(254,400\right.$ plants ha $\left.^{-1}\right)$ to higher seed rates, the grain yield decreased significantly. Higher grain yield in sorghum cultivar sorghum 2011 was recorded under narrower row spacing of 30-45 cm. Row spacing primarily influences the number of plants $\mathrm{m}^{-2}$ (stem densitym ${ }^{-2}$ ) and results of the grain yield are considered to be more dependent, or attribute of, plant to plant space using seed rate, row to row distance, different establishing techniques or the planting geometry etc. The present study indicates that the plant characters such as stem diameter and plant height are affected by the plant population, depending upon the seed rate or the plant spacing, where stem diameter was negatively affected, while the plant height was positively affected, with increase in the seed rate. Both the parameters are, in common observation, are affected oppositely as plant height or tiller height increases, the stem diameter decreases. Seed rate and spacing effect was recorded to enhance one of the above parameter and had the contrary effect on the other. Higher seed rate or wider row spacing, within a given seed rate giving more number of plants per row, produces thinner plants that are more vulnerable to lodging. The plant characteristics such as stem diameter, density $\mathrm{m}^{-2}$, number of heads per plant and number of grains per head were inferred to be improved in the treatment combination of lowest seed rate and $30 \mathrm{~cm}$ row spacing, and the same combination producing better sorghum grain yield. Hence, $5 \mathrm{~kg} \mathrm{ha}^{-1}$ seed rate of Sorghum with $30 \mathrm{~cm}$ row spacing is considered to be the optimum for higher grain yield.

\section{REFERENCES}

Andrade, F.H., Calvino, P., Cirilo, A., and Baebieri, P. (2002). Yield responses to narrow row depend on increased radiation interception. Agronomy Journal, 94 (10), 113-118.

Ayub, M., Tanveer, A., Nadeer, M.A., and Tayyab, M. (2003). Fodder yield and quality of sorghum as influenced by different tillage method and seed rates. Pakistan Journal of Agronomy, 2(3), 179-184. 
Bryant, H.H., Touchto, J.T., and Moore, D.P. (1986). Narrow row and early planting produce top grain sorghum yields. Highlights Agriculture Research Alabama Agricultural Experiment Station, 33, Article 5.

Caliskan, S., Aslan, M., Uremis, I., and Caliskan, M.E. (2007). The effect of row spacing on yield and yield component of full season and double cropped soybean. Turk Journal of Agriculture, 31147-31154.

Caravetta, C.J., Cherney, J., and Johnson, H. (1990).Within row spacing influences on diverse sorghum genotypes. 1. Morphology. Agronomy Journal, 82(2), 206-210.

Cox, W.J. (1996). Whole plant physiological and yield responses of maize to plant density. Agronomy Journal, 88, 489-496.

De Bruin, J.L. and Pederson, P. (2008). Effect of row spacing and seeding rate on soybean yield. Agronomy Journal, 100, 204-210.

Fernandez, C.J., Fromme, D.D., and Grichar, W.J. (2012).Grain sorghum response to row spacing and plant populations in the Texas coastal Bend region. International Journal of Agronomy, Article ID 238634, P.6.

Geleta, B., Atak, M., Baenziger, P.S., Nelson, L.A., Baltenesperger, D.D., Eskridge, K.M., Shipmam, M.J., and Shelton, D.R. (2002). Seeding rate and genotype effect on agronomic performance and end use quality of winter wheat. Crop Science, 42, 827832.

Habyarimana, E., Bonardi, P., Laureti, D., Di Bari, V., Cosentino, S., and Lorenzoni, C. (2004). Multilocational evaluation of biomass sorghum hybrids under two stand densities and variable water supply in Italy. Indian Crops Production, 20, 3-9.

Johnson, WA., Prostko, E.P., and Mullinix, B.G. (2005). Improving the management of dicot weedsin peanut with narrow row spacings and residual herbicides. Agronomy Journal, 97(1), 85-88.

Karchi, Z. and Rudich, Y. (1966). Effects of row width and seedling spacing on yield and its components in grain sorghum grown under dryland conditions. Agronomy Journal, 58, 602-604.

Kashiwagi, T., Togawa, E., Hirotsu, N., and Ishimaru, K. (2008). Improvement of lodging resistance with QTLs for stem diameter in rice (Oryza sativa L.)Theory and Applied Genetics, 117, 749-757.

Krishnareddy, S.R., Stewart, B.A., Payne, W.A., Robinson, C.A., and Thomason R.C. (2006). Tillering in dryland grain sorghum clumps as influenced by light, planting density and geometry. Southern Conservation Systems Conference, Amarillo TX, June 26-28.

Lemerle, D., Verbeek, B., and Diffy, S. (2006). Influence of field pea (Pisumsativum) density on grain yield and competitiveness with annual rye grass (Loliumrigidum) in southeastern Australia. Australian Journal of Experimental Agriculture, 46, 1465-1472.

Lemerle, D., Causens, R.D., Gill, L.S., Peltzer, S.J., Moerkerk, M., Murphy, C.E., Collins, D., and Cullis, B.R. (2004). Reliability of higher seed rates of wheat for increased competitiveness with weeds in low rainfall environment. Journal of Agriculture Sciences, 142, 395-409. 
Mascagni, H.J., and Bell, B. (2005). Plant patterns for different grain sorghum hybrids, Louisiana Agriculture Magazine, 2005.

(http://www.isuageenter.com/en/communications/publications/agmag/archive/2005/winter/pla $\mathrm{nt}+$ patterns+for+different+grain+sorghum+hybrids.htm)

McMurray, L. (2004). Plant density inputs Kaspa field pea's grain yield. Australian Farm Journal, 45-46.

McRae, F.J., McCaffery D.W., and Mathews, P.W. (2008). Winter crop variety sowing guide. NSW, Department of Primary Industries, 74-85.

Pawlowski, F., Jedruszczak, M., and Bojarezyk, M. (1993). Yield of soybean on loens soil depending on row spacing and sowing rate. Field Crop Abstracts, 46(2), 978.

Rana, J.S., and Ahuja, K.N. (1986). Response of mungbean varieties to different row spacings.Indian Journal of Agronomy, 31(3), 308-309.

Schmitt, J., and Wulff, R.D. (1993). Light spectral quality, phytochrome and plant competition. Trends Ecology \& Evolution, 8, 47-51.

Snider, J.L., Raper, R.L., and Schwab, E.B. (2012).The effect of row spacing and seed rate on biomass production and plant stand characteristics of non-irrigated photoperiodsensitive sorghum (Sorghum bicolor L. Moench). Industrial Crops and Products, 37, 527-535.

Srivastava, S.N., Namdeo, K.N., Tripathi, A.R. and Pandey, R.P. (1980). Effect of row spacings and levels of phosphorus on blackgram (Vigna mungo, var. RadiataHepper).Madras Agriculture Journal, 67(12), 771-773.

Staggenborg, S.A. (1999). Grain sorghum response to row spacings and seeding rates in Kansas. Journal of Production Agriculture, 12(3), 390-395.

Steiner, J.L. (1986). Dryland grain sorghum water use, light interception and growth response to planting geometry. Agronomy Journal, 78, 720-726.

Stickler, F.C., and Laude, H.H. (1960). Effect of row spacing and plant population on performance of corn, grain sorghum and forage sorghum. Agronomy Journal, 52, 275277.

Van Der Werf, H.M.G., Wijlhuizen, M., and de Shutter, J.A.A. (1995). Planting density and self-thinning affect yield and quality of fibre hemp (Cannabis sativa L.). Field Crops Research, 40,153-164.

Venuto, B., and Kindiger, B. (2008). Forage and biomass feedstock production from hybrid forage sorghum and sorghum sudan grass hybrids. Grassland Science, 54, 189-196.

Widdicombe, W.D., and Thelen, K.D. (2002). Row width and plant density effects on corn grain production in the northern Corn Belt. Agronomy Journal, 94, 1020-1023.

Walker, R.H., and Buchanan, G.A. (1982).Crop manipulation in integrated weed management systems. Weed Science, 30, 17-24.

Wortmann, C.S., Liska, A.I., Ferguson, R.B., Lyon, D.I., Klein, R.N., and Dweikat, I. (2010). Dryland performance of sweet sorghum and grain crops for biofuel in Nebraska, Agronomy Journal, 102, 319-326. 